Elsevier required licence: (c) <2019>.

This manuscript version is made available under the CC-BY-NC-ND 4.0 license

http://creativecommons.org/licenses/by-nc-nd/4.0/

The definitive publisher version is available online at

https://www.sciencedirect.com/science/article/pii/S0301421519305981?via\%3Dihub 


\title{
Stakeholders strategies in poverty alleviation and clean energy access: A case study of China's PV poverty alleviation program
}

\author{
Li Xu ${ }^{1,2}$, Qin Zhang ${ }^{1,2}$, Xunpeng Shi * 3,4,5
}

1 College of Economics and Management, Nanjing University of Aeronautics and Astronautics, Nanjing 210016, China Email: xu_li2016@163.com; qin_zhang_nuaa@126.com

2 Research Centre for Soft Energy Science, Nanjing University of Aeronautics and Astronautics, Nanjing 210016, China

3 Australia-China Relations Institute, University of Technology Sydney, Ultimo NSW 2007, Australia. Email: Xunpeng.shi@gmail.com

4 Center of Hubei Cooperative Innovation for Emissions Trading System \& School of Low Carbon Economics, Hubei University of Economics, Wuhan, China

5 Energy Studies Institute, National University of Singapore, Singapore 119620

* Corresponding Author: xunpeng.shi@uts.edu.au; Tel.: +61 431002760

\begin{abstract}
Poverty reduction and access to clean energy are two challenges highlighted in the UN Sustainable Development Goals. China's Photovoltaic (PV) Poverty Reduction Program provides an archetype model to address those two questions simultaneously. Using a tripartite game of government, enterprise and household, this paper examines the challenges that have impeded the development of China's PV poverty alleviation program. Based on an evolutionary game model and the Graph Model for Conflict Resolution (GMCR) model involving the three major parties, this study shows that: (1) Governmental monitoring and the active participation of both enterprises and households are essential to achieve a win-win-win outcome; (2) The government plays a leading role in monitoring and encouraging the active participation of enterprises and households and resolving the conflicts between enterprises and households; and (3) Households should have a minimum share in the project. The analyses imply the following policy suggestions such as ensuring optimal path selection for all parties, avoiding the abandonment of projects, increasing households' sense of ownership and creating accessible finance.
\end{abstract}

Keywords: Poverty alleviation; access to clean energy; China; PV; evolutionary game; GMCR;

\section{Introduction}

Accessing to clean energy, and consequently reduce carbon emission, and eradication of poverty are two of the 17 goals among the "UN Sustainable Development Goals (SDG)" that have been unanimously agreed upon by all nations to work towards 2030 (UN, 2018).

While there is a wide consensus on the interlinkage between poverty and energy access, little work has been done to solve both issues simultaneously at a large scale (Shi et al., 2016). Building on its success in developing the PV industry (Zhu et al., 2019), China's PV 
Poverty Alleviation Initiate (hereafter, the Program) may provide an archetype model that

In the Program, instead of providing cash or other material support to poor households, the governments help each poor household install a solar PV station, such as rooftop solar PV panels, of $5 \mathrm{~kW}$ and guarantee buy back the electricity at fixed prices (NDRC et al., 2016). Over the expected PV panel's life of 20 years, the poor households will have certain amount of continuous revenue. The government finance the PV units, and households may also need to co-finance. Yet the policies and practice are different across the provinces and in some provinces, households do not co-finance (XNA, 2018). In some cases, enterprises that constructs the systems can also finance or co-finance the systems in exchange for case return or other benefits, such as license to building commercial power plants in Hebei province (XNA, 2018). In some cases, enterprises build and operate the stations and collect all the revenue while paying fixe amount to the households that install the station. In this Program, the households can gain both stable and continuous income while access to clean energy and reduction carbon emission. If such Program can be sustainable as it envies, it can be a role model for other developing countries as there is low requirement on government's capacity which is often absent in development countries.

However, the Program runs into many problems, mainly capital shortage, poor quality of constructed PV units, and operation/maintenance issues (NAOPRC, 2017a, 2017b, 2016). Each of the three key parties, government, enterprise, and household are accountable. The government may not have sufficient fiscal resources to finance all systems, or have not paid enough monitoring to project quality and thus leads to short lived PV systems (ECERB, 2016). The households have no interest to maintain the systems if their revenue is not linked to the system operation and they do not have an ownership. The enterprises who finance the systems, have not received the financial revenue due to malfunction of the systems, or have 
not received in-kind benefits from the governments (Zhu, 2016). While there are a few understanding how to put the three parties together to implement the Program.

This paper constructs a tripartite evolutionary game among the government, enterprises, and households and employs the GMCR model to explore how the three parties' revenues can be balanced so as to create a "win-win-win" situation. This paper makes the following contributions: (1) establishes an evolutionary game model among the three parties; (2) uses the GMCR model to obtain the equilibrium solution based on the information of the PV poverty alleviation parties, and analyzes the causes of the conflict when it occurs; and (3) investigates the challenges in China's PV poverty alleviation program.

The simulations calibrated with real data offer insights and bring to light implications that have hitherto not been discovered. The study of China's PV poverty alleviation experience is not only important for China, but also for the world. There has been no such combined effort at a scale comparable to even China's provincial level. Only a few documents have covered China's PV poverty alleviation, and they all emphasize the combing and summarization of policies (Geall et al., 2018; Li et al., 2018; Zhang et al., 2018a). Further study of China's experience can help improve policy development in China and inform other governments in the world that similarly face the dual challenges of sustainable energy development and poverty reduction.

The remainder of this paper is organized as follows. Section 2 reviews the literature on the poverty game relationship and presents the background of the Program. Section 3 puts forwards a tripartite evolutionary game model, the model's basic assumptions and each party's decision analysis. Section 4 examines the tripartite evolutionary game equilibrium. Section 5 analyses a tripartite conflict event in Ningxia using the GMCR. Section 6 draws conclusions and puts forward policy proposals. 


\section{Background and literature review}

\subsection{Clean energy access and poverty reduction}

Energy alone does not lift people out of poverty, but access to energy is a prerequisite for economic growth, education, transportation, environment and health (Lenz et al., 2017; Nadimi and Tokimatsu, 2018; Sagar, 2005; Stram, 2016). Many studies have demonstrated the benefits of integrating poverty alleviation into broader agenda of economic development. For example, Chirambo (2018) notes that emphasizing rural electrification and linking energy use to agriculture and irrigation may have the effect of alleviating poverty, promoting industrialization, promoting gender equality and reducing the vulnerability of climate change in sub-Saharan Africa. In contrast, in India, because the poor do not get the true benefits of energy subsidies which impedes their access to clean energy, the poverty alleviation programs have not conducted clean energy supply as a basic infrastructure service (Dhingra et al., 2008). Zhang et al., (2019) discuss that broader rural development plans such as poverty reduction and industrialization should include rural electrification to make power projects sustainable.

Renewable energy is hoped as a means to alleviate poverty. Mainali et al. (2018) study how to improve energy and water services by locally available biomass resources (cow dung and agricultural residues) in rural community of Bangladesh. As a means of addressing poverty reduction and climate change, Yadoo and Cruickshank (2012) explore the operability of renewable energy to provide sustainable welfare (social, technical, 
environmental, institutional and economic) in developing countries including Nepal, Peru and Kenya.

Poor households without access to energy in developing countries are seen as the main market for renewable energies (Liu et al., 2019; Xu et al., 2019). The United Nations Framework Convention on Climate Change, the Kyoto Protocol and the Climate Convention clearly suggest that poor households should be emphasized on the climate discussions although they are reported to contribute only low GHG (Green House Gas) emissions (Sagar, 2005). Through an integrated assessment model, Glomsrød et al. (2016) study that China can mitigating global carbon dioxide $\left(\mathrm{CO}_{2}\right)$ emissions at 2015 level while reducing poverty by providing much more pensions, medical services and good education in rural areas until 2030.

However, the niche market between the poor and renewable energy could not succeed because of a lack of commercial viability and thus no little private sector interest. Provision of modern energy almost free of charge has no commercial significance and does not motivate private entrepreneurs (Bhattacharyya, 2006). Mboumboue and Njomo (2016) study the relationship between livelihood of the poor and renewable energy, and find that less than $10 \%$ of rural population in Cameroon could enjoy modern energy. Bhattacharyya (2006) find subsidies for solar home systems could benefit the poor effectively in Nepal, and by 2011, $27 \%$ of eligible households had installed the system with about $25 \%$ of them below the poverty line. Unfortunately, without external intervention, many governments are not able to fund renewable energy for energy poverty in rural areas (Stram, 2016). 


\subsection{China's PV poverty alleviation model}

The China's PV Poverty Alleviation Program demonstrates various scenarios of reducing poverty while improving access to clean energy. While governments provide fiscal support to some projects in the Program, in other cases, the governments do not make financial contribution. The private enterprises are also motivated to invest in projects under the Program for benefits from the projects and beyond the projects (e.g., get some public franchises). Given the limit and even non-fiscal contribution from the governments, the Chinese case could offer lessons for other developing countries that often lack of fiscal resources.

China has played a key role in global poverty reduction. In 2015, it accounted for over $70 \%$ of global poverty reduction (UN, 2015). According to current rural poverty standards (2,300 yuan per person per year), the number of rural poor in China decreased by 730 million, and the incidence of poverty dropped from $97.5 \%$ in 1978 to $4.5 \%$ in 2016 (Rural Socio-economic Survey Team of National Bureau of Statistics, 2017). In view of problems in poverty alleviation programs and the goal of lifting the remaining poor people out of poverty by 2020, the Chinese government decided in December 2013 to implement targeted measures for poverty alleviation (GOCPC and GOSC, 2013).

In October 2014, the Chinese government issued the PV Poverty Alleviation Work Program, which declared the first six PV poverty alleviation pilot provinces and provided them with instructions (NEA and SCLGOPAD, 2014). The government also put forward the "Ten Programs for Targeted Poverty Alleviation", of which the PV program was included (Lin, 2015). By August 31, 2018, the Chinses government had allocated 15,440 megawatt (MW) of PV poverty alleviation projects, and completed 13,630 MW in 26 provinces, helping 2.24 million poverty-stricken households (NEA, 2019). 
Although PV poverty alleviation program has made great achievements, there have been some problems (NAOPRC, 2017a, 2017b, 2016): (i) As of June 2016, three of the first six pilot provinces -- Shanxi, Gansu and Ningxia -- did not complete the program, with Ningxia completing only $12.88 \%$ of the plan; and (ii) the transmission systems were not ready to connect all projects. As the transmission capacity was not enough, 21 of the $26 \mathrm{PV}$ projects were not connected to the grid in time in Tangxian, Hebei, representing 3.8 million yuan in poverty relief funds; (iii) the anticipated per-capita income of households was around 3,000 yuan. But in reality, the lowest income was merely $300 \mathrm{CNY}$ (Zhu, 2016). The reasons included initial capital shortage, poor quality of constructed PV stations, and operation/maintenance issues. Access to finance is one of the key constraints to China's renewable energy revolution. Ji and Zhang, (2019) find that financial development account for $42.42 \%$ of the change in the renewable energy growth. The three major capital sources of the PV poverty alleviation projects were poor households, enterprises and governments (as shown in Figure 1), whose ratio of contributions was of vital significance to the success of a project. If a large amount of funding was required, poor households and enterprises would be discouraged. On the other hand, the financial burdens of governments would be too great if their capital proportion was too high.

Another source of problems was the lack of monitoring. In April, 2019, the State Council Leading Group Office of Poverty Alleviation and Development (SCLGOPAD) released the "Notification on the power generation of village-level photovoltaic poverty alleviation station", including 15,695 village-level PV poverty alleviation power stations. According to the assessments in the document, 3,103 power stations, or $19.8 \%$ of the total, 
has less than $80 \%$ of the power generation capacity. The main reasons for the

under-utilization of power generation capacity are unqualified construction quality, unfulfilled main responsibility of operation and maintenance, and inadequate operation and maintenance management. This result suggest that the PV poverty alleviation power stations still needs strict follow-up supervision to guarantee to achieve their poverty alleviation goal.

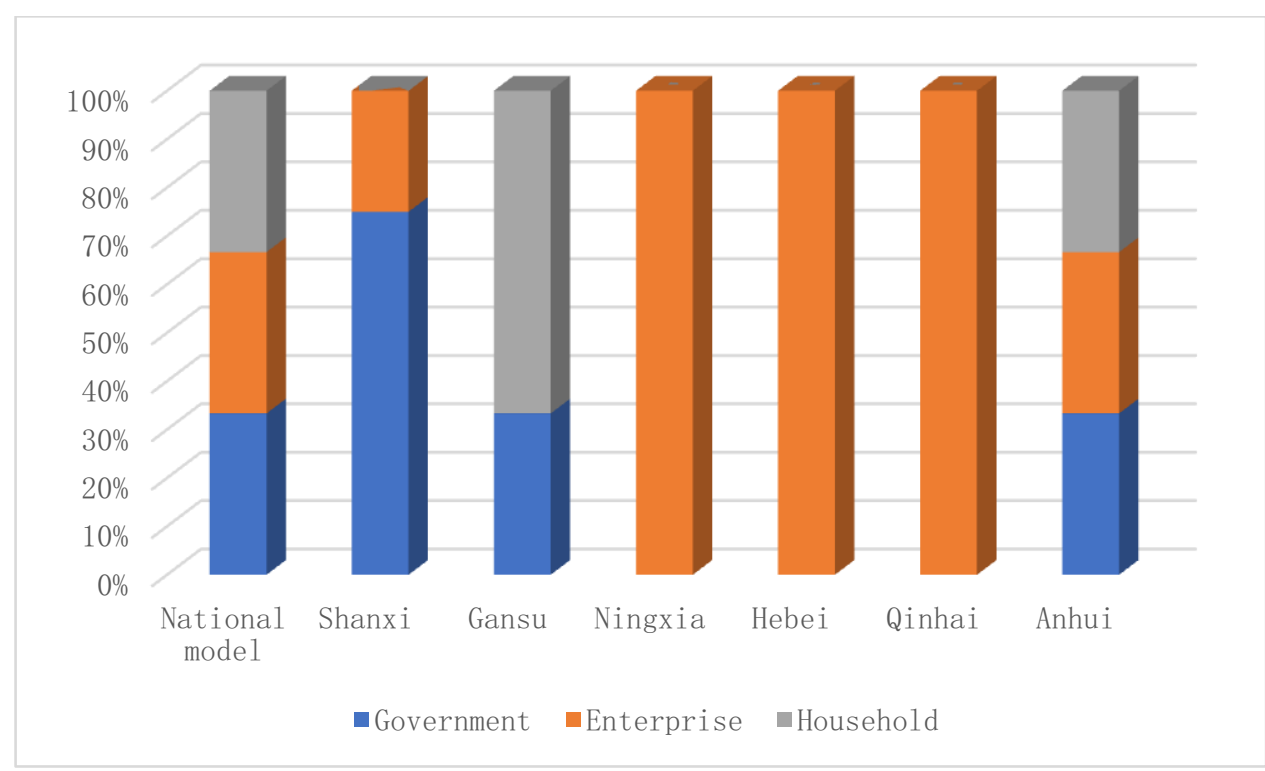

Figure 1. Project fund raising policies of various provinces. Source: XNA, (2018)

\subsection{The application of models to PV poverty alleviation}

There are a few papers about PV poverty alleviation, using modeling. Liao and Fei, (2019) study the targets of PV poverty alleviation projects and apply a spatial approach to examine the decisive factors of its implementation. They find that counties which are included in the implementation plans are spatially clustered, while enormous challenges such as poor grid infrastructure, low population density, and low economic activities in these areas constraint the implementation of PV poverty alleviation projects. Zhang et al., (2018) compare three different financial models (dynamic game model), which are 1) the government's full investment, 2) poor households' loan plus poverty alleviation funds, and 3) companies' investment plus poverty alleviation funds. They indicate that the return and the 
range of poverty reduction by companies' investment are higher than the other two methods.

Li et al., (2019) apply an agent-based model in a multiplex network to analyze companies' potential reputational benefits from their economic performance in $\mathrm{PV}$ poverty alleviation projects, and find many companies are willing to participate in these poverty alleviation projects for the potential revenue brought by the improvement of their companies' social reputation. Shan and Yang, (2019) build a tripartite evolutionary game model of poor households, PV companies, and the government to discuss their behavior strategies, and find that the equilibrium point is when poor households, $\mathrm{PV}$ enterprises and the government choose the strategies of "participation", "initiative support" and "not supervision", respectively. It is different from our result that we find the strategies of "participation", "initiative support" and "supervision" is the equilibrium point, which means that we indicate the government's supervision is a key to achieve the win-win-win situation.

While all these papers discuss and study the successful initial of the projects, none of them finds a solution for the conflicts in the PV poverty alleviation by empirical analysis We discuss how to create a "win-win-win" situation in the photovoltaic poverty alleviation project at startup by building an evolutionary game among the government, enterprises, and households and employ the GMCR model to discuss the strategies of the three parties in the conflict in the projects that have already been launched, taking the problem in Helan county, Ningxia province as an example, and explore how the three parties' revenues can be balanced.

\section{A government-enterprise-household evolutionary game model}

The evolutionary game theory was first applied to the analysis of game behavior among animals (Maynard Smith, 1974). There have been a great number of studies that use the evolutionary game theory to explain the evolution of cooperative behaviors, such as dynamic networks (Fu et al., 2007; Melamed and Simpson, 2016; Raub et al., 2013; Rezaei and Kirley, 
2012), and preferential selection (Deng et al., 2016; Shi et al., 2009). The behavior patterns in 
- The government has the option to monitor the project after construction or not (The

\begin{tabular}{|c|c|c|c|c|c|c|c|c|c|}
\hline Party & Strategy name & \multicolumn{8}{|c|}{ Strategies } \\
\hline Governments & 1.monitoring & $\mathrm{N}$ & $\mathrm{N}$ & $\mathrm{N}$ & $\mathrm{N}$ & $\mathrm{Y}$ & $\mathrm{Y}$ & $\mathrm{Y}$ & $\mathrm{Y}$ \\
\hline Enterprises & 2.positive participation & $\mathrm{N}$ & $\mathrm{N}$ & Y & Y & $\mathrm{N}$ & $\mathrm{N}$ & $\mathrm{Y}$ & $\mathrm{Y}$ \\
\hline Households & 3.positive participation & $\mathrm{N}$ & $\mathrm{Y}$ & $\mathrm{N}$ & $\mathrm{Y}$ & $\mathrm{N}$ & $\mathrm{Y}$ & $\mathrm{N}$ & $\mathrm{Y}$ \\
\hline Strategies & & S1 & $\mathrm{S} 2$ & S3 & S4 & S5 & S6 & S7 & S8 \\
\hline
\end{tabular}

Note: $\mathrm{N}$ : passive participation; $\mathrm{Y}$ : positive participation. 


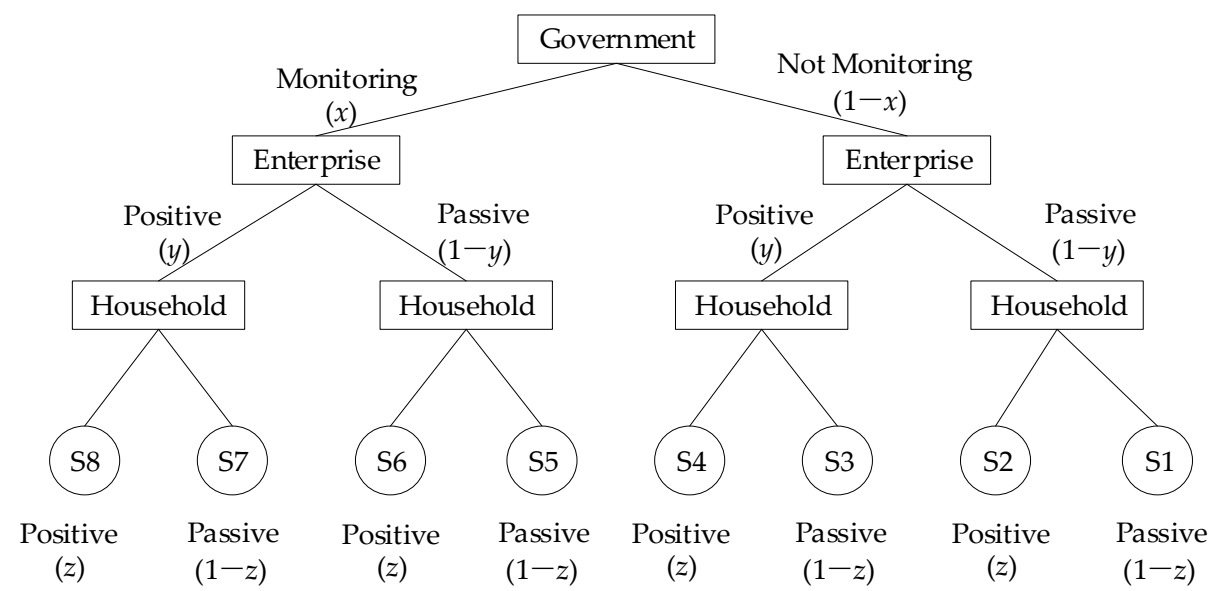

Figure 2. Decision tree

\subsection{Parameters and income matrix}

We obtained the parameters from the literature such as Shan and Yang (2019) and Zhang et al. (2018a) and calibrated them through interviews of all the three stakeholders. We interviewed ten government officials, eight companies' managers and several households participating in the PV poverty alleviation projects. The details value of the parmaters are presented in Table 2 .

The income of the three parties under the eight different strategies are calculated respectively with the parameters of Table 2 (Refer to Table 3).

Then, the evolutionary game model is employed to analyze the decision-making behavior of governments, enterprises and households, respectively. 
Table 2. Main parameters and their implications

\begin{tabular}{|c|c|c|}
\hline Parameters & Implication & Assignment \\
\hline$C_{11}$ & Government monitoring costs when households are actively involved & 1 \\
\hline$C_{12}$ & Government monitoring costs when households participate negatively & 6 \\
\hline$C_{21}$ & $\begin{array}{l}\text { The costs faced by enterprises, such as the time paid and costs of production, } \\
\text { when governments regulate, and enterprises actively participate }\end{array}$ & 4 \\
\hline$C_{22}$ & $\begin{array}{l}\text { The costs faced by enterprises, such as the time paid and costs of production, } \\
\text { when governments do not regulate, and enterprises actively participate }\end{array}$ & 3 \\
\hline$C_{31}$ & $\begin{array}{l}\text { The costs faced by households, such as capital and manpower, when } \\
\text { enterprises actively participate, and households participate actively }\end{array}$ & 3 \\
\hline$C_{32}$ & $\begin{array}{l}\text { The costs faced by households, such as capital and manpower, when } \\
\text { enterprises are negatively involved, and households participate actively }\end{array}$ & 2 \\
\hline$U_{1}$ & $\begin{array}{l}\text { The total benefits of the government's PV poverty alleviation project, } \\
\text { including economic and environmental benefits, etc. }\end{array}$ & I \\
\hline$U_{2}$ & $\begin{array}{l}\text { The total benefits that enterprises receive from government funds, low-interest } \\
\text { loans, tax incentives, etc. }\end{array}$ & I \\
\hline$U_{3}$ & The benefits for households in active participation & 8 \\
\hline$U_{4}$ & The benefits for households in passive participation & 4 \\
\hline$P$ & $\begin{array}{l}\text { The enterprises' passive participation is punished by governments after } \\
\text { discovery, such as a certain number of direct fines, or withdrawing the } \\
\text { preferential funds before the policy }\end{array}$ & 5 \\
\hline$N$ & The negative effects of passive poverty alleviation on society & $1(\gamma N)$ \\
\hline$G_{1}$ & $\begin{array}{l}\text { The positive social impacts of the government when enterprises actively } \\
\text { participate }\end{array}$ & / \\
\hline$G_{2}$ & $\begin{array}{l}\text { The positive social impacts of enterprises when they actively participate, and } \\
\text { then they can get some public franchises }\end{array}$ & $1\left(\beta G_{2}\right)$ \\
\hline$\alpha$ & $\begin{array}{l}\text { The positive social impacts coefficient of governments when they actively } \\
\text { participate, increasing with time }\end{array}$ & I \\
\hline$\beta$ & $\begin{array}{l}\text { The positive social impacts coefficient of enterprises when they actively } \\
\text { participate, increasing with time }\end{array}$ & I \\
\hline$\gamma$ & $\begin{array}{l}\text { The negative impact coefficient of passive poverty alleviation for society, } \\
\text { increasing with time }\end{array}$ & I \\
\hline$M_{1}$ & $\begin{array}{l}\text { Governments compensate households when they regulate, and households are } \\
\text { actively involved }\end{array}$ & 1 \\
\hline$M_{2}$ & $\begin{array}{l}\text { Governments compensate households when they do not regulate, and } \\
\text { households are actively involved. The number if large than } M_{1} \text { as saved cost } \\
\text { from regulation can be allocated to households }\end{array}$ & 3 \\
\hline$E$ & $\begin{array}{l}\text { The extra benefits that enterprises receive between active and passive } \\
\text { participations of households when the enterprises are actively participate }\end{array}$ & 2 \\
\hline$Q$ & $\begin{array}{l}\text { The extra benefits that households receive between active and passive } \\
\text { participations of enterprises while the households are passively participate }\end{array}$ & 1 \\
\hline
\end{tabular}

Table 3. The income of each party

\begin{tabular}{clll}
\hline strategies & Government income & \multicolumn{1}{c}{ Enterprise income } & \multicolumn{1}{c}{ Household income } \\
\hline S8 & $U_{1}+\alpha G_{1}-C_{11}-M_{1}$ & $U_{2}+\beta G_{2}-C_{21}$ & $U_{3}-C_{31}+M_{1}$ \\
S7 & $U_{1}+\alpha G_{1}-C_{12}$ & $U_{2}+\beta G_{2}-C_{21}+E$ & $U_{4}+Q$ \\
S6 & $U_{1}+P-C_{11}-\gamma N-M_{1}$ & $U_{2}-P-\gamma N$ & $U_{3}-C_{32}+M_{1}$ \\
S5 & $U_{1}+P-C_{12}-\gamma N$ & $U_{2}-P-\gamma N$ & $U_{4}$ \\
S4 & $U_{1}+\alpha G_{1}-M_{2}$ & $U_{2}+\beta G_{2}-C_{22}$ & $U_{3}-C_{31}+M_{2}$ \\
S3 & $U_{1}+\alpha G_{1}$ & $U_{2}+\beta G_{2}-C_{22}+E$ & $U_{4}+Q$ \\
S2 & $U_{1}-\gamma N-M_{2}$ & $U_{2}-\gamma N$ & $U_{3}-C_{32}+M_{2}$ \\
S1 & $U_{1}-\gamma N$ & $U_{2}-\gamma N$ & $U_{4}$ \\
\hline
\end{tabular}




\subsection{Governmental decision analysis}

The expected benefits of governmental monitoring and the group's average benefit are respectively: $\pi_{1 x}$ and $\pi_{1}$

$$
\begin{gathered}
\pi_{1 x}=y z\left(U_{1}+\alpha G_{1}-C_{11}-M_{1}\right)+y(1-z)\left(U_{1}+\alpha G_{1}-C_{12}\right)+(1-y) z\left(U_{1}+P-\right. \\
C 11-\gamma N-M 1+1-y 1-z U 1+P-C 12-\gamma N, \\
\pi_{1}=x y z\left(U_{1}+\alpha G_{1}-C_{11}-M_{1}\right)+x y(1-z)\left(U_{1}+\alpha G_{1}-C_{12}\right)+x(1-y) z\left(U_{1}+P-\right. \\
C 11-\gamma N-M 1+x 1-y 1-z U 1+P-C 12-\gamma N+(1-x) y z U 1+\alpha G 1-M 2+ \\
(1-x) y(1-z)\left(U_{1}+\alpha G_{1}\right)+(1-x)(1-y) z\left(U_{1}-\gamma N-M_{2}\right)+(1-x)(1-y)(1- \\
z U 1-\gamma N,
\end{gathered}
$$

When governments choose monitoring, the replicated dynamics equation is:

$$
F(x)=\frac{d x}{d t}=x\left(\pi_{1 x}-\pi_{1}\right)=x(1-x)\left[z\left(C_{12}-C_{11}-M_{1}+M_{2}\right)-y P+P-C_{12}\right],
$$

(1) when $C_{12}-P=z\left(C_{12}-C_{11}-M_{1}+M_{2}\right)-y P, F(x) \equiv 0$, this means that all levels are stable. Regardless of the size of the proportion that the government group chooses to monitor, the strategies will not change over time.

(2) when $C_{12}-P \neq z\left(C_{12}-C_{11}-M_{1}+M_{2}\right)-y P$, if $F(x)=0$ then $x=0$ and $x=1$ are two stable points. ESS requirement that $\frac{d F(x)}{d x}$ is negative at the stable point,

$$
\frac{d F(x)}{d x}=(1-2 x)\left[z\left(C_{12}-C_{11}-M_{1}+M_{2}\right)-y P+P-C_{12}\right],
$$

(i) when $C_{12}-P<z\left(C_{12}-C_{11}-M_{1}+M_{2}\right)-y P,\left.\frac{d F(x)}{d x}\right|_{x=1}<0,\left.\frac{d F(x)}{d x}\right|_{x=0}>0$, so $x=1$ is the stable point;

(ii) when $C_{12}-P>z\left(C_{12}-C_{11}-M_{1}+M_{2}\right)-y P,\left.\frac{d F(x)}{d x}\right|_{x=1}>0,\left.\frac{d F(x)}{d x}\right|_{x=0}<$ 0 ,so $x=0$ is the stable point.

From (2), when $C_{12}-P<z\left(C_{12}-C_{11}-M_{1}+M_{2}\right)-y P$, under the constrains of $0 \leq x \leq 1,0 \leq y \leq 1,0 \leq z \leq 1$, we get $C_{12}-P<C_{12}-C_{11}-M_{1}+M_{2}-P$, and thus the government chooses to regulate. Therefore, it is essential to control parameter values to keep $C_{11}+M_{1}<M_{2}$. This result suggests that local governments take their own costs into account. When the government regulates, the government cost is the regulation cost $\left(C_{11}\right)$ plus the 
compensation to the households $\left(M_{1}\right)$; When the government does not regulate, the government spends less on regulation than no-regulation $\left(C_{11}+M_{1}<M_{2}\right)$, the government will choose the regulation strategy ( $x$ to 1$)$.

3.4 Enterprise decision analysis

The expected benefits of active participation by enterprises and the group's average benefits are respectively: $\pi_{2 y}$ and $\pi_{2}$

$$
\begin{gathered}
\pi_{2 y}=x z\left(U_{2}+\beta G_{2}-C_{21}\right)+x(1-z)\left(U_{2}+\beta G_{2}-C_{21}+E\right)+(1-x) z\left(U_{2}+\beta G_{2}-\right. \\
C 22+1-x 1-z U 2+\beta G 2-C 22+E, \\
\pi_{2}=x y z\left(U_{2}+\beta G_{2}-C_{21}\right)+x y(1-z)\left(U_{2}+\beta G_{2}-C_{21}+E\right)+(1-x) y z\left(U_{2}+\right. \\
\beta G 2-C 22+1-x y 1-z U 2+\beta G 2-C 22+E+(1-y) x z U 2-P-\gamma N+x(1-y) 1-z U 2-P-\gamma N \\
+1-x(1-y) z U 2-\gamma N+1-x(1-y) 1-z U 2-\gamma N,
\end{gathered}
$$

When enterprises choose active participation, the replicated dynamics equation is:

$$
F(y)=\frac{d y}{d t}=y\left(\pi_{2 y}-\pi_{2}\right)=y(1-y)\left[-z E+x\left(C_{22}-C_{21}+P\right)+\gamma N+\beta G_{2}+E-\right.
$$

\section{C22,}

(1) when $C_{22}-E-\beta G_{2}-\gamma N=-z E+x\left(C_{22}-C_{21}+P\right), F(\mathrm{y}) \equiv 0$, this means that all levels are stable. Regardless of the proportion that the enterprise group choose in terms of active and passive participation, the strategies will not change over time.

(2) when $C_{22}-E-\beta G_{2}-\gamma N \neq-z E+x\left(C_{22}-C_{21}+P\right)$, if $F(y)=0$, then $y=$ 0 and $y=1$ are two stable points.

$$
\frac{d F(y)}{d y}=(1-2 y)\left[-z E+x\left(C_{22}-C_{21}+P\right)+\gamma N+\beta G_{2}+E-C_{22}\right]
$$

(i) When

$$
C_{22}-E-\beta G_{2}-\gamma N<-z E+x\left(C_{22}-C_{21}+P\right)
$$

$$
\left.\frac{d F(y)}{d y}\right|_{y=1}<0,\left.\frac{d F(y)}{d y}\right|_{y=0}>0, \text { so } y=1 \text { is the stable point; }
$$


(ii)

$$
\text { when } \quad C_{22}-E-\beta G_{2}-\gamma N>-z E+x\left(C_{22}-C_{21}+P\right)
$$

$\left.\frac{d F(y)}{d y}\right|_{y=1}>0,\left.\frac{d F(y)}{d y}\right|_{y=0}<0$, so $y=0$ is the stable point.

From (2), when $C_{22}-E-\beta G_{2}-\gamma N<-z E+x\left(C_{22}-C_{21}+P\right)$, under the constrains of $0 \leq x \leq 1,0 \leq y \leq 1,0 \leq z \leq 1$, we get $C_{22}-E-\beta G_{2}-\gamma N<-E+C_{22}-C_{21}+$ $P$, and thus enterprises choose active participation. Therefore, it is essential to control parameter values to keep $C_{21}<\beta G_{2}+\gamma N+P$. This suggests that the key parameter that determines enterprises' actively participation in PV poverty alleviation is to reduce the costs when there is no government regulation $\left(C_{21}\right)$. The indirect motivation of enterprises to actively participate is to enhance their cooperate image and expand their influence (by increasing $\beta G_{2}$ ). In order to prevent enterprises from pursuing passive poverty alleviation strategies, the governments can increase the punishments of violation of regulations $(P)$ and expand the negative social influences of enterprises $(\gamma N)$. These measures will prompt enterprise choose active participation ( $y$ to 1$)$.

\subsection{Household decision analysis}

The expected benefits of active participation by households and the group's average benefits are respectively: $\pi_{3 z}$ and $\pi_{3}$

$$
\begin{gathered}
\pi_{3 z}=x y\left(U_{3}-C_{31}+M_{1}\right)+x(1-y)\left(U_{3}-C_{32}+M_{1}\right)+(1-x) y\left(U_{3}-C_{31}+M_{2}\right)+ \\
(1-x)(1-y)\left(U_{3}-C_{32}+M_{2}\right), \\
\pi_{3}=x y z\left(U_{3}-C_{31}+M_{1}\right)+x(1-y) z\left(U_{3}-C_{32}+M_{1}\right)+(1-x) y z\left(U_{3}-C_{31}+M_{2}\right)+ \\
(1-x)(1-y) z\left(U_{3}-C_{32}+M_{2}\right)+x y(1-z)\left(U_{4}+Q\right)+x(1-y)(1-z) U_{4}+ \\
(1-x) y(1-z)\left(U_{4}+Q\right)+(1-x)(1-y)(1-z) U_{4},
\end{gathered}
$$

When households choose active participation, the replicated dynamics equation is:

$$
\begin{gathered}
F(z)=\frac{d z}{d t}=z\left(\pi_{3 z}-\pi_{3}\right)=z(1-z)\left[y\left(C_{32}-C_{31}-Q\right)+x\left(M_{1}-M_{2}\right)+U_{3}-U_{4}+\right. \\
\left.M_{2}-C_{32}\right]
\end{gathered}
$$

(1) When $U_{4}-U_{3}-M_{2}+C_{32}=y\left(C_{32}-C_{31}-Q\right)+x\left(M_{1}-M_{2}\right), F(z) \equiv 0$, this means that all levels are stable. Regardless of the proportions that the household group chooses in terms of active and passive participation, the strategies will not change over time. 
(2) When $U_{4}-U_{3}-M_{2}+C_{32} \neq y\left(C_{32}-C_{31}-Q\right)+x\left(M_{1}-M_{2}\right)$, if $F(z)=0$, then $z=$

$$
\frac{d F(z)}{d z}=(1-2 z)\left[y\left(C_{32}-C_{31}-Q\right)+x\left(M_{1}-M_{2}\right)+U_{3}-U_{4}+M_{2}-C_{32}\right],
$$

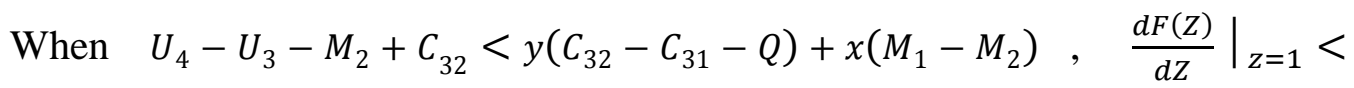
$0,\left.\frac{d F(Z)}{d z}\right|_{z=0}>0$, so $z=1$ is the stable point;

$$
\begin{aligned}
& \text { When } U_{4}-U_{3}-M_{2}+C_{32}>y\left(C_{32}-C_{31}-Q\right)+x\left(M_{1}-M_{2}\right),\left.\frac{d F(Z)}{d Z}\right|_{z=1}>0, \\
& \left.\frac{d F(Z)}{d Z}\right|_{z=0}<0 \text {, so } z=0 \text { is the stable point. }
\end{aligned}
$$

From (2), when $U_{4}-U_{3}-M_{2}+C_{32}<y\left(C_{32}-C_{31}-Q\right)+x\left(M_{1}-M_{2}\right)$, under the constrains of $0 \leq x \leq 1,0 \leq y \leq 1,0 \leq z \leq 1$, we get $U_{4}-U_{3}-M_{2}+C_{32}<C_{32}-C_{31}-$ $Q+M_{1}-M_{2}$, and thus the households will choose active participate. Therefore, it is essential to control parameter values to keep $U_{4}+C_{31}+Q<M_{1}+U_{3}$. The households' active participating in PV poverty alleviation program could be boosted ( $z$ to 1 ): if the government increases the compensation for the active participation to the households $\left(M_{1}\right)$, or the government helps the households by financial and material resources through multiple channels to reduce the cost of the active participation of them $\left(C_{31}\right)$, or the government can guarantee the continuous and steady increase of the benefits of the active participation of the households $\left(U_{3}\right)$. The households who feel the benefits of negative participation $\left(U_{4}\right.$, and $\left.C_{31}=0\right)$ and the amount of money that enterprises give them $(Q)$ are less than the benefits of active participation will also choose to participate actively ( $z$ to 1$)$.

\section{Tripartite equilibrium analysis at startup stage}

\subsection{Equilibrium rresults}

The game equilibrium state of the whole system is analyzed after discussing the dynamic process of the game. 
If $\frac{d x}{d t}=0, \frac{d y}{d t}=0, \frac{d z}{d t}=0$, the 14 equilibrium points of the game system are obtained (see Table 4):

Table 4. The 14 equilibrium points

\begin{tabular}{|c|c|c|c|c|c|}
\hline $\begin{array}{l}\text { Equilibrium } \\
\text { points }\end{array}$ & & $\begin{array}{c}\text { Probability of } \\
\text { governmental regulation } \\
(\mathrm{X})\end{array}$ & $\begin{array}{c}\text { Probability of } \\
\text { enterprises' active } \\
\text { participation }(y)\end{array}$ & $\begin{array}{l}\text { Probability of households' } \\
\text { active participation (z) }\end{array}$ & \\
\hline E1 & ( & 0 & 0 & 0 & ) \\
\hline E2 & ( & 0 & 0 & 1 & ) \\
\hline E3 & ( & 0 & 1 & 0 & ) \\
\hline E4 & ( & 0 & 1 & 1 & ) \\
\hline E5 & ( & 1 & 0 & 0 & ) \\
\hline E6 & ( & 1 & 0 & 1 & ) \\
\hline E7 & ( & 1 & 1 & 0 & ) \\
\hline E8 & ( & 1 & 1 & 1 & ) \\
\hline E9 & ( & 0 & $\frac{U_{3}-U_{4}+M_{2}-C_{32}}{C_{31}-C_{32}+Q}$ & $\frac{\gamma N+\beta G_{2}+E-C_{22}}{E}$ & ) \\
\hline E10 & ( & 1 & $\frac{M_{1}+U_{3}-U_{4}-C_{32}}{C_{31}-C_{32}+Q}$ & $\frac{-C_{21}+F+\gamma N+\beta G_{2}+E}{E}$ & ) \\
\hline E11 & & $\underline{U_{3}-U_{4}+M_{2}-C_{32}}$ & & $-P+C_{12}$ & ) \\
\hline E12 & ( & $\begin{array}{c}M_{2}-M_{1} \\
-C_{31}-Q+U_{3}-U_{4}+M_{2} \\
\end{array}$ & 0 & $\frac{C_{12}-C_{11}-M_{1}+M_{2}}{C_{12}}$ & ) \\
\hline E13 & ( & $\begin{array}{c}M_{2}-M_{1} \\
\frac{\gamma N+\beta G_{2}+E-C_{22}}{C_{21}-C_{22}-P}\end{array}$ & $\frac{P-C_{12}}{P}$ & $\begin{array}{c}C_{12}-C_{11}-M_{1}+M_{2} \\
0\end{array}$ & ) \\
\hline E14 & ( & $\frac{\gamma N+\beta G_{2}-C_{22}}{C_{21}-C_{22}-P}$ & $\frac{P-C_{11}-M_{1}+M_{2}}{P}$ & 1 & ) \\
\hline
\end{tabular}

Note: The proportion of governments choosing to monitor is $x$, the proportion of enterprises choosing to actively reduce poverty is $y$, the proportion of households' positive participation is $z$.

According to the local stability analysis method proposed by Friedman (1991), the Jacobian matrix $\mathrm{J}$ is obtained by the partial derivative of three replication dynamic equations.

$$
\begin{gathered}
\left\{(1-2 x)\left[z\left(C_{12}-C_{11}-M_{1}+M_{2}\right)-y P+P-C_{12}\right]-x(1-x) P x(1-x)\left(C_{12}-\right.\right. \\
\left.C_{11}-M_{1}+M_{2}\right) ; y(1-y)\left(C_{22}-C_{21}+P\right)(1-2 y)\left[-z E+x\left(C_{22}-C_{21}+P\right)+\gamma N+\right. \\
\left.\beta G_{2}+E-C_{22}\right]-P y(1-y) ; z(1-z)\left(M_{1}-M_{2}\right) z(1-z)\left(C_{32}-C_{31}-Q\right)(1- \\
\left.2 z)\left[y\left(C_{32}-C_{31}-Q\right)+x\left(M_{1}-M_{2}\right)+U_{3}-U_{4}+M_{2}-C_{32}\right]\right\},
\end{gathered}
$$

The 14 equilibrium points are substituted into $\mathrm{J}$, and by the Lyapunov stability theorem, the equilibrium point is the stable point when the non-positive characteristic root of $\mathrm{J}$ matrix is 3. When the non-positive number is 0 , the equilibrium point is unstable. When the number of non-positive Numbers is between 0 and 3, the equilibrium point is the saddle point. 
A further elaboration of the 14 equilibrium points is explained by the following numerical study.

\subsection{Numerical study}

We calibrated the parameters according to the literature and also tried to make them as realistic as possible, even when they were hypothetical due to the lack of empirical data (Cheng et al., 2017; Shan and Yang, 2019).

In order to ensure the rationality of the numerical example, in September 2017 we interviewed some parties in PV poverty alleviation projects located in Helan County which is situated in China's Ningxia Hui Autonomous Region, including six government officers, eight enterprise managers and six households. Based on the interviews, we decided the relative parameters (see the last column of Table 2) under the tripartite game model of governments, enterprises and households. All values were normalized.

We also made some reasonable assumptions relating to the parameters:

(1) The cost of governmental monitoring when the households participate passively is always greater than that when the households participate actively $\left(C_{11}<C_{12}\right)$. For example, after the official commissioning of the PV poverty alleviation power station, if households actively participate, they would actively maintain and inspect the power station, reducing the pressure for government monitoring. On the contrary, when households participate passively, the government must invest more manpower and material resources to monitor the power stations in order to ensure the benefits, and this increases the costs of monitoring.

(2) The cost of an enterprise's active investment under government monitoring is greater than that when the government does not monitor $\left(C_{22}<C_{21}\right)$. When there is government regulation, enterprises must undergo government inspections and this costs money. On the other hand, the fear of government punishment causes enterprises to choose to invest more than this cost. 
(3) Households get more benefits from active participation compared to passive

participation $\left(U_{3}>U_{4}\right)$.

The parameters in the last column of Table 2 are substituted into each equilibrium point and Jacobian matrix, and the eigenvalues of the Jacobian matrix which correspond to each equilibrium point are obtained. The stability of each equilibrium point can be determined by this, as shown in Table 5. In this case, because $E_{9} \sim E_{14}$ are not satisfying $0 \leq x \leq 1$, $0 \leq y \leq 1,0 \leq z \leq 1$, they are invalid equilibrium points, and no eigenvalues are calculated and analyzed.

Table 5. Stability analysis of the equilibrium points

\begin{tabular}{ccc}
\hline Equilibrium points & Eigenvalues & Status \\
\hline$E_{1}=(0,0,0)$ & $(-1,1,3)$ & saddle point \\
$E_{2}=(0,0,1)$ & $(6,-1,-3)$ & saddle point \\
$E_{3}=(0,1,0)$ & $(-6,-1,1)$ & saddle point \\
$E_{4}=(0,1,1)$ & $(1,1,-1)$ & saddle point \\
$E_{5}=(1,0,0)$ & $(1,5,4)$ & unstable point \\
$E_{6}=(1,0,1)$ & $(-6,3,-4)$ & saddle point \\
$E_{7}=(1,1,0)$ & $(6,-5,2)$ & saddle point \\
$E_{\mathbf{8}}=(\mathbf{1}, \mathbf{1}, \mathbf{1})$ & $(-\mathbf{1},-\mathbf{3},-\mathbf{2})$ & ESS \\
$E_{9}=(0,5 / 2,1 / 2)$ & -- & -- \\
$E_{10}=(1,3 / 2,5 / 2)$ & -- & -- \\
$E_{11}=(5 / 2,0,1 / 7)$ & -- & -- \\
$E_{12}=(3 / 2,1,6 / 7)$ & -- & -- \\
$E_{13}=(-1 / 4,-1 / 5,0)$ & -- & -- \\
$E_{14}=(1 / 4,6 / 5,1)$ & -- & \\
\hline
\end{tabular}

It can be seen from Table 5 that the stable equilibrium point of the tripartite game is $(1,1$, 1) (E8), that is, the government chooses to monitor, the enterprises choose positive participation in poverty alleviation program and the households choose to active participation.

The initial state of the region will converge to $E_{8}=(1,1,1)$, when the initial state satisfies condition $(5 y+1) / 7<z \leq 1,(4 x+1) / 7<z \leq 1$, and the parameters are 
assigned to each replicated dynamic equation. The evolution area of the stable equilibrium point is shown in Figure 3.

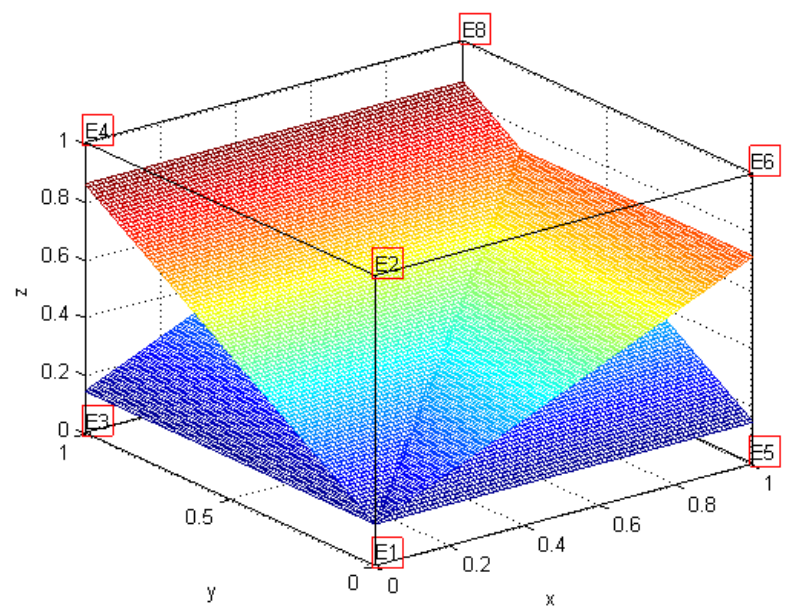

Figure 3. Evolution Area of the stable equilibrium point

For the conditions to be satisfied by the initial state, the $\mathrm{z}$ value is the key. This means that the proportion of active participation by the households must be greater than the benchmark (like $z>1 / 7$ in the above case) in order to achieve tripartite balance. When trying to eradicate poverty, it is far better to teach households how to fish, rather than to give them fish (Keita and Mandon, 2017). This implies that encouraging households to make the active decision to invest so as to reap a higher income is much more effective than passive giving.

For the $\mathrm{z}$ assignment, we can get $\mathrm{x}$ and $\mathrm{y}$ correspondingly to meet the equilibrium conditions (see Table 6). As $\mathrm{z}$ increases, the range of $\mathrm{x}$ and $\mathrm{y}$ increases, and the value of $\mathrm{x}$ is always greater than $y$. This means that to achieve a tripartite win-win-win outcome, the most important thing is households' active engagement. The more that active households take part, the more the governments take part in monitoring, and the more that enterprises actively participate, the easier it is to achieve equilibrium. 
Table 6. The initial conditions for reaching the equilibrium point in the case of different $\mathrm{z}$ values

\begin{tabular}{ccccc}
\hline No. & $\boldsymbol{z}$ & $\boldsymbol{y}$ & $\boldsymbol{x}$ & $\begin{array}{c}\text { An example of an initial state of } \\
\text { equilibrium } \\
(\mathbf{x}, \mathbf{y}, \mathbf{z})\end{array}$ \\
\hline 1 & $z=2 / 7$ & $\mathrm{y}<1 / 5$ & $\mathrm{x}<1 / 4$ & $(1 / 5,1 / 6,2 / 7)$ \\
2 & $z=3 / 7$ & $\mathrm{y}<2 / 5$ & $\mathrm{x}<1 / 2$ & $(1 / 3,1 / 5,3 / 7)$ \\
3 & $z=4 / 7$ & $\mathrm{y}<3 / 5$ & $\mathrm{x}<3 / 4$ & $(1 / 2,2 / 5,4 / 7)$ \\
4 & $z=5 / 7$ & $\mathrm{y}<4 / 5$ & $\mathrm{x}<1$ & $(5 / 6,3 / 5,5 / 7)$ \\
5 & $z=6 / 7$ & $\mathrm{y}<1$ & $\mathrm{x}<1$ & $(4 / 5,4 / 5,6 / 7)$ \\
6 & $z=1$ & $\mathrm{y} \leq 1$ & $\mathrm{x} \leq 1$ & $(1,1,1)$ \\
\hline
\end{tabular}

In terms of investment in Figure 1, there were three provinces in which households did not participate and did not conform to the equilibrium condition. Consequently, it was difficult to achieve a win-win-win situation, and thus the households' earnings were not guaranteed. In contrast, for the reference model given by the National Energy Administration (NEA) (NEA, 2015), the proportion of the three parties' contribution ratios were the same and consistent with the situation in Table 6, which could achieve equilibrium.

\section{Tripartite conflict events in established projects: a case study of Helan County}

The game decision of each party in the PV poverty alleviation program at startup was discussed above. Now we discuss the decision of the three parties in the conflict of projects that had already been launched, taking the problem in Helan County as an example (Zhu, 2016).

Six districts and counties in Ningxia were designated as pilot areas for PV poverty alleviation program in 2015. Helan County was one of them. In 2016, a total of 4,999 people in 998 households were registered in Helan County, and 1,231 people were lifted out of poverty (County-Helan, 2018a).

By September 2017, all the 5-megawatt rooftop distributed PV projects in Helan County were connected to the grid, benefiting 1,500 households with a yearly dividend of 300 yuan per household (County-Helan, 2018b). This income was less than 10\% of the target income 
of "PV poverty alleviation" determined by the state. The reason for this was the Ningxia model. According to Ningxia's PV poverty alleviation model, the enterprises fully invested in the PV construction, and give poor households 3,000 yuan a year. As a return, the governments promises to give the enterprises more than $3000 \mathrm{mu}$ of land for PV agricultural projects (Zhu, 2016). However, after the PV power stations were built, the enterprise did not get the land). Therefore, the enterprises only give 300 yuan per month to the households as the cost of retaining their rooftops (County-Helan, 2018b; Zhu, 2016). Without fulfill its commitments, the government instead as the households to purchase the power station. But households had no money to buy back these power station, and consequently, the project jammed. The experience of Helan County showed that the interests of the enterprises and households were neglected. This practice could damage not only the interests of the enterprises and households, it could also damage the governments' credibility and the development of the local economies.

Using the analytical model presented in Section 3, we demonstrate why the Ningxia model caused the failure.

\subsection{Decision-makers and strategies}

The main goals of each household (HOU) are to increase its own income and to rise out of poverty as quickly as possible. Their two strategies are:

H1: Appeal: appeal to the government (GOV) to solve the problem of low income; or

$\mathrm{H} 2$ : Buy: purchase the stations using self-financing, the estimate payback period is 5 years or so. Net profit will be generated after the payback period. .

The main aims of the government are to prevent further deterioration of the conflict, maintain stability and resolve conflicts. Their three strategies are:

G1: Coordinately solve: fulfil their commitments to the enterprises (ENT); or 
G2: Appeal: requests its superior government to expand the poverty alleviation funds to solve the income problem of households; or

G3: Delay: slowly fulfil its commitments to the enterprises and delays to solve the problems of poor households

The main goals of enterprises are to maximize their profits and avoid losses. Their two strategies are:

E1: Appeal: appeal to the government to solve the problem of concessions; or

E2: Quit: exit the project and write off their investment.

\subsection{Feasible states and transitions}

According to the above analysis, there are seven strategies by three decision-makers and two states in logic. But when it comes to making decisions, each decision-maker makes only one decision each time, for example, households do not choose to buy back when they appeal. Remove the unfeasible states and leave 12 possible states (see Table 7).

Table 7. Feasible states of conflict events

\begin{tabular}{llcccccccccccc}
\hline DM & Options & s1 & s2 & s3 & s4 & s5 & s6 & s7 & s8 & s9 & s10 & s11 & s12 \\
\hline HOU & H1. appeal & N & N & N & N & N & N & Y & Y & Y & Y & Y & Y \\
& H2. buy & Y & Y & Y & Y & Y & Y & N & N & N & N & N & N \\
& & & & & & & & & & & & & \\
GOV & G1. coordinately solve & N & N & N & N & Y & Y & N & N & N & N & Y & Y \\
& & & & & & & & & & & & & \\
& G2. appeal & N & N & Y & Y & N & N & N & N & Y & Y & N & N \\
& G3. delay & Y & Y & N & N & N & N & Y & Y & N & N & N & N \\
ENT & E1. appeal & N & Y & N & Y & N & Y & N & Y & N & Y & N & Y \\
& E2. quit & Y & N & Y & N & Y & N & Y & N & Y & N & Y & N \\
\hline
\end{tabular}

According to the feasible states (see Table 7), we can draw state transition diagrams of the three parties (see Figures 4, 5, and 6). State transition refers to whether the decision-maker can move from one state to another, when other decision-makers' strategies remain unchanged. The arrow indicates that it can be transferred from one state to another. 
The double arrows indicate that the two states are reversible and can move each other. For example, it indicates $\mathrm{S} 1$ can transfer to $\mathrm{S} 7$ for the household's decision and vice versa in Figure 4.

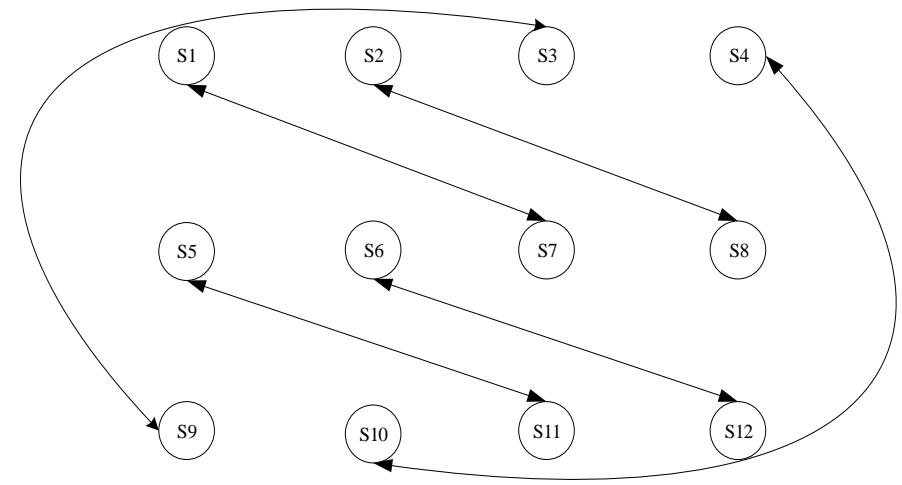

Figure 4. Household state transition diagram model

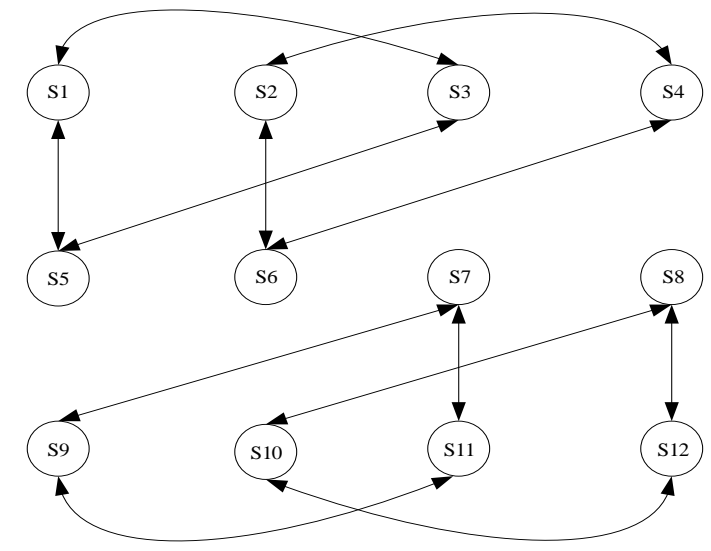

Figure 5. Government state transition diagram model 

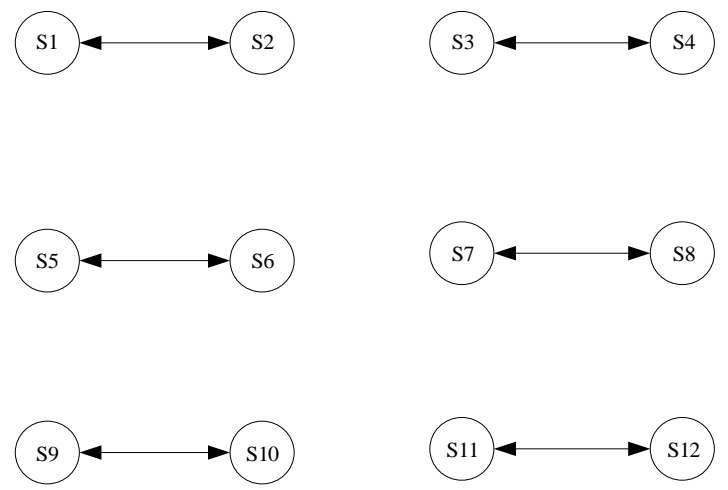

Figure 6. Enterprise state transition diagram model

\subsection{Preference information}

This paper mainly adopts the policy priority ranking method (Xu et al., 2013) to obtain the preference information of each party. According to the actual background of the conflict, we investigated and interviewed government officers, business leaders and poor households, so as to determine the declaration of preference of each of the three parties, as shown in Table 8. It is important to note that there are two kinds of governmental preference, namely economic preference and people's livelihood preferences. The priority sequence method is used to obtain the following sequence of the state's preference.

(1) HOU: $\mathrm{S} 10>\mathrm{s} 9>\mathrm{s} 12>\mathrm{s} 11>\mathrm{s} 8>\mathrm{s} 7>\mathrm{s} 4>\mathrm{s} 3>\mathrm{s} 6>\mathrm{s} 5>\mathrm{s} 2>\mathrm{s} 1$

(2) GOV:

2a. Economic preference: $\mathrm{s} 6>\mathrm{s} 12>\mathrm{s} 5>\mathrm{s} 11>\mathrm{s} 4>\mathrm{s} 2>_{\mathrm{s} 10}>\mathrm{s} 8>\mathrm{s} 3>_{\mathrm{s}} 1>_{\mathrm{s}} 9>\mathrm{s} 7$

2b. People's livelihood preference: $s 9>\mathrm{s} 10>\mathrm{s} 3>_{\mathrm{s}} 4>\mathrm{s} 11>\mathrm{s} 12>\mathrm{s} 7>\mathrm{s} 8>\mathrm{s} 5>\mathrm{s} 6>_{\mathrm{s}} 1>\mathrm{s} 2$

(3) ENT: s6>s12 >s5 $>\mathrm{s} 11>\mathrm{s} 4>\mathrm{s} 10>\mathrm{s} 2>\mathrm{s} 8>\mathrm{s} 3>\mathrm{s} 9>\mathrm{s} 1>\mathrm{s} 7$

\subsection{Analysis of conflict stability}

Using conflict analysis ( $\mathrm{Li}$ et al., 2016), the equilibrium results are defined in four basic stabilities (Nash stability, general metarationality (GMR), symmetric metarationality (SMR), and sequential stability (SEQ),) (see Table 9 and Table 10). 
The equilibrium solution is indicated as" * " under column E of each party. When all

four kinds of stabilities are achieved, the state is considered to be in equilibrium.

Table 8. The preferences of the decision-makers and their implications

\begin{tabular}{|c|c|c|}
\hline DM & Preference & $\begin{array}{l}\text { Explanation } \\
\end{array}$ \\
\hline \multirow{7}{*}{$\mathrm{HOU}$} & $\mathrm{H} 1$ & Hopefully, the government will solve it. \\
\hline & G2 & Hopefully, the local government will help themselves. \\
\hline & G1 & $\begin{array}{l}\text { Hopefully, the government will also solve the problem of } \\
\text { enterprise. }\end{array}$ \\
\hline & E1 & Hopefully, enterprises will actively strive. \\
\hline & $-\mathrm{G} 3$ & Don't want to be delayed. \\
\hline & $-\mathrm{E} 2$ & Don't want enterprises to quit, and the project ends. \\
\hline & $\mathrm{H} 2$ & $\begin{array}{l}\text { Hopefully, they can borrow and buy back, and the long-term } \\
\text { benefits are their own. }\end{array}$ \\
\hline \multirow{7}{*}{ GOV (Economic preference) } & G1 & First, solve enterprises' problem. \\
\hline & E1 & Hopefully, enterprises will strive for themselves. \\
\hline & $-\mathrm{E} 2$ & Don't want enterprises to quit. \\
\hline & $\mathrm{H} 2$ & $\begin{array}{l}\text { Hopefully, households can borrow and buy back, and the } \\
\text { long-term benefits are their own. }\end{array}$ \\
\hline & $-\mathrm{H} 1$ & Do not want households to appeal and intensify the conflict. \\
\hline & $\mathrm{G} 2$ & Their job is to strive more for households. \\
\hline & G3 & Work habits. \\
\hline \multirow{7}{*}{$\begin{array}{l}\text { GOV (People's livelihood } \\
\text { preferences) }\end{array}$} & G2 & First, strive more for households. \\
\hline & $\mathrm{H} 1$ & Hopefully, households strive for themselves. \\
\hline & $-\mathrm{H} 2$ & Repo is too difficult for households. \\
\hline & G1 & Solve the enterprises' problem. \\
\hline & $-\mathrm{E} 1$ & $\begin{array}{l}\text { Do not want the enterprises to appeal and intensify the } \\
\text { conflict. }\end{array}$ \\
\hline & $-\mathrm{E} 2$ & Don't want the enterprises to quit. \\
\hline & G3 & Work habits. \\
\hline \multirow{7}{*}{ ENT } & G1 & Hopefully, the local government will help themselves. \\
\hline & E1 & Strive for their own good. \\
\hline & $\mathrm{G} 2$ & Hopefully, the problem of poverty will be solved. \\
\hline & $-\mathrm{G} 3$ & Don't want to be delayed. \\
\hline & $\mathrm{H} 2$ & $\begin{array}{l}\text { Hopefully, households can borrow and buy back, and the } \\
\text { long-term benefits are their own. }\end{array}$ \\
\hline & $\mathrm{H} 1$ & Hopefully, households strive for themselves. \\
\hline & E2 & In the event of a great loss of interest, they will quit. \\
\hline
\end{tabular}

Note: the higher the order of the preference, the more valuable to the party. A negative value means that the party does not want it to happen. 
Table 9. Stability analysis results when the government is under economic preference

\begin{tabular}{|c|c|c|c|c|c|c|c|c|c|c|c|c|c|c|c|c|}
\hline \multirow{2}{*}{$\begin{array}{l}\text { stat } \\
\mathrm{e}\end{array}$} & \multicolumn{4}{|c|}{ Nash } & \multicolumn{4}{|c|}{ GMR } & \multicolumn{4}{|c|}{ SMR } & \multicolumn{4}{|l|}{ SEQ } \\
\hline & Hou & Gov & Ent & $\mathrm{E}$ & Hou & Gov & Ent & $\mathrm{E}$ & Hou & Gov & Ent & $\mathrm{E}$ & $\mathrm{Hou}$ & Gov & Ent & $\mathrm{E}$ \\
\hline $\mathrm{s} 1$ & & & & & & & & & & & & & & & & \\
\hline $\mathrm{s} 2$ & & & 1 & & & & 1 & & & & 1 & & & & 1 & \\
\hline s3 & & & & & & & & & & & & & & & & \\
\hline s4 & & & 1 & & & & 1 & & & & 1 & & & & 1 & \\
\hline s5 & & 1 & & & & 1 & 1 & & & 1 & 1 & & & 1 & & \\
\hline s6 & & 1 & 1 & & & 1 & 1 & & & 1 & 1 & & & 1 & 1 & \\
\hline s7 & 1 & & & & 1 & & & & 1 & & & & 1 & & & \\
\hline s8 & 1 & & 1 & & 1 & & 1 & & 1 & & 1 & & 1 & & 1 & \\
\hline s9 & 1 & & & & 1 & & & & 1 & & & & 1 & & & \\
\hline s10 & 1 & & 1 & & 1 & & 1 & & 1 & & 1 & & 1 & & 1 & \\
\hline s11 & 1 & 1 & & & 1 & 1 & 1 & $*$ & 1 & 1 & 1 & $*$ & 1 & 1 & & \\
\hline $\mathrm{s} 12$ & 1 & 1 & 1 & $*$ & 1 & 1 & 1 & $*$ & 1 & 1 & 1 & $*$ & 1 & 1 & 1 & $*$ \\
\hline
\end{tabular}

Note: '1' indicates the optimal strategy of the corresponding decision maker

Table 10. Stability analysis results when the governments are under people's livelihood preference

\begin{tabular}{|c|c|c|c|c|c|c|c|c|c|c|c|c|c|c|c|c|}
\hline \multirow{2}{*}{$\begin{array}{l}\text { stat } \\
\mathrm{e}\end{array}$} & \multicolumn{4}{|l|}{ Nash } & \multicolumn{4}{|c|}{ GMR } & \multicolumn{4}{|l|}{ SMR } & \multicolumn{4}{|l|}{ SEQ } \\
\hline & Hou & Gov & Ent & E & Hou & Gov & Ent & $\mathrm{E}$ & Hou & Gov & Ent & $\mathrm{E}$ & $\mathrm{Hou}$ & Gov & Ent & $\mathrm{E}$ \\
\hline \multicolumn{17}{|l|}{ s1 } \\
\hline s2 & & & 1 & & & & 1 & & & & 1 & & & & 1 & \\
\hline s3 & & 1 & & & & 1 & & & & 1 & & & & 1 & & \\
\hline s4 & & 1 & 1 & & & 1 & 1 & & & 1 & 1 & & & 1 & 1 & \\
\hline s5 & & & & & & & 1 & & & & 1 & & & & 1 & \\
\hline s6 & & & 1 & & & & 1 & & & & 1 & & & & 1 & \\
\hline s7 & 1 & & & & 1 & & & & 1 & & & & 1 & & & \\
\hline s8 & 1 & & 1 & & 1 & & 1 & & 1 & & 1 & & 1 & & 1 & \\
\hline s9 & 1 & 1 & & & 1 & 1 & & & 1 & 1 & & & 1 & 1 & & \\
\hline s10 & 1 & 1 & 1 & $*$ & 1 & 1 & 1 & $*$ & 1 & 1 & 1 & $*$ & 1 & 1 & 1 & * \\
\hline s11 & 1 & & & & 1 & & 1 & & 1 & & 1 & & 1 & & 1 & \\
\hline $\mathrm{s} 12$ & 1 & & 1 & & 1 & & 1 & & 1 & & 1 & & 1 & & 1 & \\
\hline
\end{tabular}

Note: ' 1 ' indicates the optimal strategy of the corresponding decision maker

The equilibrium results obtained under different governments' preferences are different. The equilibrium strategy under governments' economic preference is s12 (defined in Table 7) (see Table 9), while it is s10 (defined in Table 7) under the people's livelihood preference (see Table 10). The difference is that in s12, governments prefer to fight for the enterprises (G1, and -G2), and in s10 they prefer to fight for households (-G1, and G2). 
Governments that favor economic development will give priority to solve the problems of problems of the households.

The strategies of both households and enterprises under the two equilibrium results are to choose accordingly. Under both types of governmental preference, the best decision for the households is to choose not to buy back (both in s10 and s12, the optimal strategy is $-\mathrm{H} 2)$. This is in line with reality: since for the households, the basic living standard has not been guaranteed, they cannot spend more than 20,000 yuan to buy back the PV power station.

The optimal decision for the enterprises is to appeal but not quit (both in s10 and s12, the optimal strategy is E1 and -E2). A recent study finds that public appeal is effective in promoting green investment (Liao and Shi, 2018) which suggests that appeal is effective in China. Enterprises that want to develop locally should not simply exit the project. In the case of damage to their own interests, actively communicating with the government to solve the problem and ensuring the smooth implementation of the project is the best choice for enterprises.

In the Hela case, since the government has limited fiscal revenue, it is not feasible to compensate the households. Therefore, the realistic and feasible solution to this conflict for the government is to solve the enterprises' problems, and then let the enterprises be responsible for the income of the households according to the original plan. In a nutshell, in terms of feasibility, S12 is the final equilibrium solution for the Helan county case.

Based on the above-mentioned analysis results, the causes of the conflict and the resolution process are shown in Figure 7. It can be seen that the conflict is caused by the failure of the government to fulfill its commitment to enterprises, and the key to resolving conflicts is to fulfil the governments' commitment to the enterprises. 


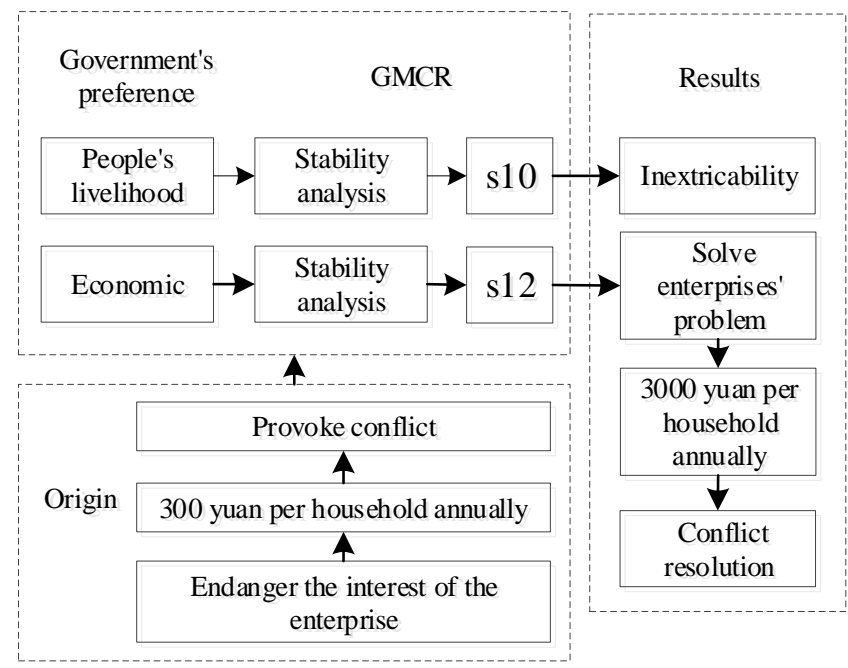

Figure 7. Dynamic interaction diagram of the tripartite conflict, illustrate with the case of Helan county

\section{Conclusion and policy implications}

PV poverty alleviation program is an innovative initiative that combines China's advancement in the solar energy industry and targeted poverty alleviation initiative. Its intent is to focus on poor households in the key poverty-stricken areas which have the necessary conditions for PV construction. While the building of power stations in the Program, measured by installed generation capacity, is impressive, there are still some problems in the implementation of the PV poverty alleviation program in various regions, such as difficulties in raising funds, the operation/maintenance of the equipment in the later stages, and insufficient monitoring and accountability. These problems are mainly related to the investment and benefit distribution among governments, enterprises and households.

Using the evolutionary game theory and GMCR method, this paper studies and discusses the solutions of the three parties to achieve a win-win-win situation and gives policy suggestions for the sustainable development of PV poverty alleviation program. The findings can help policy-makers in China to improve their projection performance. The 
Chinese model may also be replicated in other developing countries to increase access to electricity, and reduce both poverty and carbon emission simultaneously.

Based on the evolutionary game model of the three major parties in the Program and equilibrium strategy analysis, it is found that government, as the major guiding force behind PV poverty alleviation projects, are bound to take measures which stimulate and monitor enterprises and households. Governmental monitoring, enterprises' actively participate in the project investment, construction, operation and maintenance, as well as households' active participation are essential for the realization of a stable equilibrium strategy. To be specific, the enthusiasm of enterprises and households can be nurtured by the government's monitoring and policy of rewards and punishment. These also guarantee the operation and maintenance after construction so that the station can operate stably in the long run and the three parties can benefit in a sustainable way.

Through the analysis of the GMCR construction and equilibrium stabilization strategy of conflict events, it can be seen that the government is the key in solving the conflicts. The ostensible reason for conflicts was that the governments had not fulfilled their commitment to the enterprises. From the previous analysis, the fundamental reason was that the construction of the project had been $100 \%$ supported by the enterprises at the beginning of the project. Therefore, to prevent the occurrence of such conflicts, we have returned to the question of tripartite evolutionary game.

Our analysis finds that: 1) the government is capable of designing feasible behavioral routes for projects and predicting the interest equilibrium point of the three parties in different areas with the assistance of area division by tripartite equilibrium point. 2) The success of the PV poverty projects pivots on the households investing a minimum share in the project. 3) The enterprises' best strategy is to publicly appeal to the government to resolve the conflicts through negotiation. And 4) in the Helan County case, given the limited fiscal 
capacity, the feasible strategy for the government was to resolve the conflict with the enterprises first, and then let the enterprises carry on with the projects as planed so that the households' interests could be protected by the government indirectly.

Based on our study, the following policy implications can be drawn.

(1) When formulating strategies, governments should take into account the main factors that affect the return of the other two game players and guide them to choose the strategy expected by the government by controlling the changes of these factors. Governments can set parameters according to different cost and benefit functions of enterprises and households and guide the selection paths of all parties involved. In addition, the government is bound to make policies and laws favorable for the balance of the parties' long-term interests, laying a solid foundation for the sustainable development of local economies.

(2) The government needs to establish an enabling institution to guarantee and monitor the rights and responsibilities of enterprises to prevent their use of low quality products and abandoning the projects. The government should inspect the progress of the projects randomly. Appropriate amount of fines to violation needs to be set to prevent enterprise to cheating. The post project assessments and inspection results should be released to the public. The literature has demonstrated that under such public disclosure schemes, enterprise will more likely comply with contracts to avoid damaged reputations (Shi, 2014). The government should response to enterprises' appeal, in particular, fulfil its commitments, to continue the implementation of projects under the Program.

(3) Household need to have a sense of ownership of the PV Poverty Alleviation projects through equity investment. The households must contribute a minimum amount to the project investment. This prevents the neglect of the project operation by the households.

Lastly, innovative fund-raising systems need to be established to create accessible finance. Access to finance is a prevailing global challenge in rural electrification (Shi et al., 
2016; Zhang et al., 2019). While the financial inputs of both the government and households could be relieved by a number of ways.

(i) The PPP (Public-Private-Partnership) mode could provide a new path for solving finance shortage in the Program. The first PV poverty alleviation project operating in PPP mode was signed successfully in Yuexi County, Anhui Province in 2015. Through employing this mode, the pressure of lump-sum capital injection by the government can be relieved, and enterprises can earn profits from operating and managing the projects and by offering technical support. Poor households could also benefit from a successful operation of the projects (Zhang et al., 2018c).

(ii) Except the PPP mode, other steps can be taken to establish a multilevel fund-raising system. The government can pool the poverty reduction resources from different channels for better coordinated and efficient use of resources. Other innovations, such as crowd funding, loan guarantees, concessional finance, and local maintenance, can be created to reduce project costs. See Shi et al., (2016) for a comprehensive review and assessment of instruments in facilitating investment in off-grid renewable energy projects.

(iii) Increasing the financial capacity of households is another fundamental instrument to sustain the PV Poverty Alleviation project. In China, the innovative "PV+" patterns that combine PV projects with agriculture, animal husbandry, employment etc., have begun to show strong scale effects and have brought substantial gains to the rural residents. The "PV+" not only creates more jobs, but also increases local people's income through animal husbandry industries(Guan, 2016; Xinjimo, 2019).

Acknowledgments: This work was supported in part by Nanjing University of Aeronautics and Astronautics PhD short-term visiting scholar project (180610DF09), the National Science Foundation of China (71774081, 71373122, 71828401), the Basic Scientific Research Business Expenses of NUAA 
(NJ20150034, NP2017305), and the Key Project of Philosophy and Social Science Research in Universities in Jiangsu (2017ZDIXM082).

\section{References}

Bhattacharyya, S.C., 2006. Renewable energies and the poor: Niche or nexus? Energy Policy 34, 659-663. https://doi.org/10.1016/j.enpol.2004.08.009

Chen, H., Feng, Q., Cao, J., 2014. Rent-seeking mechanism for safety supervision in the Chinese coal industry based on a tripartite game model. Energy Policy 72, 140-145. https://doi.org/10.1016/j.enpol.2014.04.017

Cheng, J., Li, B., Gong, B., Cheng, M., Xu, L., 2017. The optimal power structure of environmental protection responsibilities transfer in remanufacturing supply chain. J. Clean. Prod. 153, 558-569. https://doi.org/10.1016/j.jclepro.2016.02.097

Chirambo, D., 2018. Towards the achievement of SDG 7 in sub-Saharan Africa: Creating synergies between Power Africa, Sustainable Energy for All and climate finance in-order to achieve universal energy access before 2030. Renew. Sustain. Energy Rev. 94, 600-608. https://doi.org/10.1016/j.rser.2018.06.025

County-Helan, 2018a. A list of key tasks for poverty alleviation in 2017 [WWW Document].

County-Helan, 2018b. Helan county six measures to promote poverty alleviation to the new level. [WWW Document].

Deng, X., Zhang, Z., Deng, Y., Liu, Q., Chang, S., 2016. Self-adaptive win-stay-lose-shift reference selection mechanism promotes cooperation on a square lattice. Appl. Math. Comput. 284, 322-331. https://doi.org/10.1016/j.amc.2016.03.010

Dhingra, C., Gandhi, S., Chaurey, A., Agarwal, P.K., 2008. Access to clean energy services for the urban and peri-urban poor: a case-study of Delhi, India. Energy Sustain. Dev. 12, 49-55. https://doi.org/10.1016/S0973-0826(09)60007-7

ECERB, 2016. Quality Inspection of PV Poverty Alleviation Project in 2015 in Anhui Province [WWW Document].

Friedman, D., 1991. Evolutionary Games in Economics. Econometrica 59, 637. https://doi.org/10.2307/2938222

Fu, F., Chen, X., Liu, L., Wang, L., 2007. Social dilemmas in an online social network: The structure and evolution of cooperation. Phys. Lett. Sect. A Gen. At. Solid State Phys. 371, 58-64. https://doi.org/10.1016/j.physleta.2007.05.116

Geall, S., Shen, W., Gongbuzeren, 2018. Solar energy for poverty alleviation in China: State ambitions, bureaucratic interests, and local realities. Energy Res. Soc. Sci. 41, 238-248. https://doi.org/10.1016/j.erss.2018.04.035

Glomsrød, S., Wei, T., Aamaas, B., Lund, M.T., Samset, B.H., 2016. A warmer policy for a colder climate: Can China both reduce poverty and cap carbon emissions? Sci. Total Environ. 568, 236-244. https://doi.org/10.1016/j.scitotenv.2016.06.005

GOCPC, GOSC, 2013. Opinions on Innovating Mechanism and Steadily Promoting Rural Poverty Alleviation and Development Work [WWW Document]. 
Guan, Q., 2016. Xinjiang launched a total investment of more than 7 billion yuan of photovoltaic poverty alleviation projects [WWW Document].

Ji, Q., Zhang, D., 2019. How much does financial development contribute to renewable energy growth and upgrading of energy structure in China? Energy Policy 128.

Keita, S., Mandon, P., 2017. Give a fish or teach fishing? Partisan affiliation of U.S. governors and the poverty status of immigrants. Eur. J. Polit. Econ. https://doi.org/10.1016/j.ejpoleco.2017.11.004

Lenz, L., Munyehirwe, A., Peters, J., Sievert, M., 2017. Does Large-Scale Infrastructure Investment Alleviate Poverty? Impacts of Rwanda's Electricity Access Roll-Out Program. World Dev. 89, 88-110. https://doi.org/10.1016/j.worlddev.2016.08.003

Li, J., Han, W., Xu, H., 2016. Credit expansion and concentration in China based on GMCR. J. Grey Syst. 28, 165-172.

Li, Y., Zhang, Q., Wang, G., Liu, X., Mclellan, B., 2019. Promotion policies for third party financing in Photovoltaic Poverty Alleviation projects considering social reputation. J. Clean. Prod. 211, 350-359. https://doi.org/10.1016/j.jclepro.2018.11.179

Li, Y., Zhang, Q., Wang, G., McLellan, B., Liu, X.F., Wang, L., 2018. A review of photovoltaic poverty alleviation projects in China: Current status, challenge and policy recommendations. Renew. Sustain. Energy Rev. 94, 214-223. https://doi.org/10.1016/j.rser.2018.06.012

Liao, C., Fei, D., 2019. Poverty reduction through photovoltaic-based development intervention in China: Potentials and constraints. World Dev. 122, 1-10. https://doi.org/10.1016/j.worlddev.2019.04.017

Liao, X., Shi, X. (Roc), 2018. Public appeal, environmental regulation and green investment: Evidence from China. Energy Policy 119, 554-562. https://doi.org/10.1016/j.enpol.2018.05.020

Lin, H., 2015. Promote the implementation of Ten Precision Poverty Alleviation Projects in China [WWW Document].

Liu, J., Zhang, D., Cai, J., Davenport, J., 2019. Legal systems, national governance and renewable energy investment: evidence from around the world. Br. J. Manag. https://doi.org/https://doi.org/10.1111/1467-8551.12377

Mainali, B., Ahmed, H., Silveira, S., 2018. Integrated approach for provision of clean energy and water in rural Bangladesh. Groundw. Sustain. Dev. 7, 239-249. https://doi.org/10.1016/j.gsd.2018.06.009

Maynard Smith, J., 1974. The theory of games and the evolution of animal conflicts. J. Theor. Biol. 47, 209-221. https://doi.org/10.1016/0022-5193(74)90110-6

Mboumboue, E., Njomo, D., 2016. Potential contribution of renewables to the improvement of living conditions of poor rural households in developing countries: Cameroon's case study. Renew. Sustain. Energy Rev. 61, 266-279. https://doi.org/10.1016/j.rser.2016.04.003

Melamed, D., Simpson, B., 2016. Strong ties promote the evolution of cooperation in $\begin{array}{lllll}\text { dynamic } & \text { networks. } & \text { Soc. } & \text { 32-44. }\end{array}$ https://doi.org/10.1016/j.socnet.2015.11.001

Nadimi, R., Tokimatsu, K., 2018. Energy use analysis in the presence of quality of life, 
poverty, health, and carbon dioxide emissions. Energy 153, 671-684. https://doi.org/10.1016/j.energy.2018.03.150

NAOPRC, 2017a. No. sixth on 2017: poverty alleviation audit results in 158 poor counties [WWW Document].

NAOPRC, 2017b. No. seventh 2016: audit results of the financial aid to the poor in 40 counties [WWW Document].

NAOPRC, 2016. The second quarter of 2016 national major policy measures to implement the follow-up audit results [WWW Document].

NDRC, SCLGOPAD, NEA, CDB, ADBC, 2016. Opinions on the implementation of poverty alleviation work in photovoltaic power generation [WWW Document].

NEA, 2019. A documentary on poverty alleviation by NEA in 2018. Beijing: National Energy Administration.

NEA, 2015. The photovoltaic poverty alleviation implementation plan [WWW Document].

NEA, SCLGOPAD, 2014. Notice on Printing and Distributing the Work Program of Implementing Photovoltaic Poverty Alleviation Project [WWW Document].

Raub, W., Buskens, V., Frey, V., 2013. The rationality of social structure: Cooperation in social dilemmas through investments in and returns on social capital. Soc. Networks 35, 720-732. https://doi.org/10.1016/j.socnet.2013.05.006

Rezaei, G., Kirley, M., 2012. Dynamic social networks facilitate cooperation in the N-player Prisoner's Dilemma. Phys. A Stat. Mech. its Appl. 391, 6199-6211. https://doi.org/10.1016/j.physa.2012.06.071

Rural Socio-economic Survey Team of National Bureau of Statistics, 2017. Poverty Monitoring Report of Rural China 2017. China Stat. Press 422.

Sagar, A.D., 2005. Alleviating energy poverty for the world's poor. Energy Policy 33, 1367-1372. https://doi.org/10.1016/j.enpol.2004.01.001

Shan, H., Yang, J., 2019. Sustainability of photovoltaic poverty alleviation in China: An evolutionary game between stakeholders. Energy 181, 264-280. https://doi.org/10.1016/j.energy.2019.05.152

Shi, D.M., Yang, H.X., Hu, M. Bin, Du, W.B., Wang, B.H., Cao, X. Bin, 2009. Preferential selection promotes cooperation in a spatial public goods game. Phys. A Stat. Mech. its Appl. 388, 4646-4650. https://doi.org/10.1016/j.physa.2009.07.031

Shi, X., 2014. Setting effective mandatory energy efficiency standards and labelling regulations: A review of best practices in the Asia Pacific region. Appl. Energy 133, 135-143. https://doi.org/10.1016/j.apenergy.2014.07.084

Shi, X., Liu, X., Yao, L., 2016. Assessment of instruments in facilitating investment in off-grid renewable energy projects. Energy Policy 95, 437-446. https://doi.org/10.1016/j.enpol.2016.02.001

Stram, B.N., 2016. Key challenges to expanding renewable energy. Energy Policy 96, 728-734. https://doi.org/10.1016/j.enpol.2016.05.034

UN, 2018. Sustainable development goals [WWW Document].

UN, 2015. United Nations Millennium Development Goals (2015) [WWW Document].

Xinjimo, 2019. "Photovoltaic +" opens the "fast forward" mode of rural revitalization. Qingdao: Jimo. 
